\title{
Attitudes of Teachers and Outstanding Students towards Blended Learning in Light of the Covid-19 Pandemic in Jordan
}

\author{
Samer Ayasrah ${ }^{1 *}$, Mo'en Salman Alnasraween ${ }^{2}$, Ala'aldin Alshorman ${ }^{3}$ Abdalrahman Aljarrah ${ }^{4}$ \\ 1,2 Faculty of Educational and psychological sciences, Amman Arab University, Amman, Jordan \\ ${ }^{3,4}$ The Ministry of Education, Amma, Jordan
}

\begin{abstract}
Currently, technology has become the core of development and prosperity processes in various sectors of the world, including the educational sector. The Covid-19 pandemic certainly created many problems in the educational sector, especially when the education system was completely closed, and different countries of the world sought to mitigate the effects of the pandemic on the education sector by relying on distance education (e-learning) and Blended learning. This study focuses on explaining the attitudes of teachers and outstanding students towards Blended learning in light of the Covid-19 pandemic. The study was conducted on a sample of 69 teachers and 201 outstanding students, who were chosen randomly. The results of the study revealed that the attitudes of teachers and outstanding students towards blended learning in light of the spread of the Corona virus was at an average level. The results of the study also showed that there were no statistically significant differences between teachers' and outstanding students' attitudes towards Blended learning in light of the spread of the Covid-19 pandemic due to gender. According to the grade level, from the outstanding students' point of view, it also revealed the existence of an inverse relationship and a weak degree between the teachers' tendency towards Blended learning based on the teaching experience.
\end{abstract}

Keywords: Blended learning, Covid-19, Jordan, Ooutstanding students, Teachers.

\section{INTRODUCTION}

The present era is characterized by the tremendous rapid changes resulting from scientific and technological progress in all fields, including the educational field. However, the global spread of the Covid-19 pandemic has created many crises at the global level. Among the most prominent of these crises was the general closure of the education sector in most countries of the world, as early childhood care programs, schools, and universities were stopped. This left major repercussions on nearly 1.6 billion students in 166 countries around the world (Affouneh, Salha, Khlaif, 2020; UNESCO, 2020)

With the absence of plans, strategies, and capabilities that reduce the opportunity gap in education, it is tangible and visible that the Covid-19 pandemic has caused the greatest disruption to educational opportunities around the world. Therefore, various countries of the world have sought to mitigate the effects of the Covid-19 pandemic in the educational sector by relying on distance education (e-learning) in order to continue the education process. Jordan is one of the first countries in the Arab region to respond to the Covid-19 pandemic by imposing curfews and closing all educational institutions across the Kingdom. The Ministry of Education and the Ministry of Higher Education worked hand in hand to reduce the effects of the pandemic and to sustain learning during the pandemic through the transition to distance learning tools. Nevertheless, Jordan is considered a middle-income country, and its education sector suffers from a set of severe crises (Abdul Hameed Shoman Cultural Forum, 2019; Khan \& Abdou, 2020).

Through the progress and increasing knowledge and understanding of the Covid-19 pandemic, many countries of the world have been prompted to ease quarantine restrictions and closures in general. The education sector was one of these sectors, and many countries were prompted to use Blended learning. Jordan was one of the Arab countries that sought to allow students return to schools in light of the Covid-19 pandemic at the beginning of the year (2020/2021).

This was done by relying on e-learning and employing Blended learning in the educational process, based on the principle of rotation.

Blended learning emerged as a form of e-learning in the late 1990s. It was a new and innovative way to facilitate the learning process and focus on the learner instead of the teacher in order to motivate them to use this type of learning as a new and high-quality technical method in distance learning. This was also used as a means to change teaching strategies in the educational process and in the presentation of educational content and planning for students to ensure highly effective

Corresponding Author e-mail: s.ayasrah@aau.edu.jo https://orcid.org/0000-0002-8541-7774

How to cite this article: Ayasrah S, Alnasraween MS, Alshorman A Aljarrah A (2022). Attitudes of Teachers and Outstanding Students towards Blended Learning in Light of the Covid-19 Pandemic in Jordan. Pegem Journal of Education and Instruction, Vol. 12, No. 1, 2022, 249-255

Source of support: Nil

Conflict of interest: None.

DOI: $10.47750 /$ pegegog.12.01.26

Received: 29.09.2021

Accepted: 16.12.2021 Publication: 01.01.2022 
education. Blended learning has also emerged many names and concepts since it requires the availability of advanced educational resources. In addition, it can significantly improve the efficiency of the teaching process in order to upgrade the quality of learning through the judicious application of new technologies in learning and training (Taylor, 1995; Al-Husban \& shorman, 2020; Alsalhi et al., 2019)

Due to the importance of Blended learning in the educational process, it has acquired a distinctive research importance. Thus, many research studies have sought to show the attitudes and perceptions of students and their teachers about it at the school or university level, as well as its impact on student achievement, the obstacles that limit its application, and many other variables (Almwazbh \& Zaabi, 2020; Alsalhi et al., 2019; Saifuddin, 2019; Al-Saleh, 2018; Birbal et al., 2018; Emelyanova \& Voronina, 2017; Eshreteh \& Siaj, 2017; Ja'ashan, 2015; Al-Sawalha et al., 2013; Al sied, 2011; Akkoyunlu \& Soylu, 2006).

In the midst of the spread of the Covid-19 pandemic, Basilaia et al. (2020) confirmed that there is an urgent need to move to Blended learning and use educational platforms and e-learning through which educational lectures, training courses, conferences, and educational videos can be held and shared with a large number of students very quickly. Through this means, lengthy discussions can be held and students can record and review them at later times. Since Blended learning is based on the merging of electronic and traditional education, it is flexible and effective and helps all parties to learn. It is also suitable for students in education through the use of their phones or their personal and portable computers, direct communication between teacher and student, and standardized interaction with peers.

Jordan, like the rest of the world, was directly affected by the Covid-19 pandemic, and the education sector was one of the most important sectors affected by the pandemic. Therefore, the Ministry of Education has sought to adopt distance learning (e-learning) as one of the strategic goodies to preserve students and teachers, protect them from infection with the Covid-19 virus, limit its societal spread, and ensure the continuation of the educational process. Multiple electronic platforms were also launched, including the Darasak platform which employed Blended learning according to a rotation model by dividing students into groups to attend the official school hours. This led to the optimal use of information and communication technology, the provision of Internet packages for students, and the pursuit of developing educational content in order to provide enriching educational materials to raise students' comprehension level, develop their skills and provide the capabilities that would support students' learning, enable them to access information, acquire knowledge and develop their skills to achieve educational outcomes, and to make learning more enjoyable and exciting. It also focused on upgrading the roles assigned to the teacher so that the teacher becomes a facilitator, a guide, a follower, and provide direct feedback at any time required.

The objective of this study is to determine the attitudes of teachers and outstanding students towards Blended learning in light of the Covid-19 pandemic during the first semester of 2020/2021. The Jordanian Ministry of Education applied Blended learning by adopting the rotation model as a form of electronic learning that keeps pace with scientific developments and the epidemiological situation. This study, therefore, aims to answer the following questions:

What are the teachers' attitudes towards Blended learning in light of the spread of the Covid-19 pandemic?

Are there statistically significant differences $(\alpha=0.05)$ between teachers' attitudes towards Blended learning in light of the Covid-19 pandemic according to the gender variable and teaching experience?

What are the outstanding students' attitudes towards Blended learning in light of the spread of the Covid-19 pandemic?

Are there statistically significant differences $(\alpha=0.05)$ between Outstanding students' attitudes towards Blended learning in light of the Covid-19 pandemic according to gender and grade level?

\section{Methods}

\section{Research Sample}

A random sample of 69 teachers and 201 outstanding students of the Education Directorate in the Northern Mazar District, Irbid Governorate, registering for the first semester 2020/2021 was selected for the purpose of the present study. The number of male teachers reached 35 (50.7), the number of female teachers was 34 (49.3), and the average years of experience was 3.54 .

The number of male students was 103 (51.2\%), whereas the number of female students was $98(84.8 \%)$. Based on the academic year, the sample of the study was classified as follows: Seventh-grade students represented 65 (32.3\%) of the study sample; Eighth-grade students account for 72 (35.8\%); and the Ninth-grade students constituted 64 (31.8\%) of the study sample. It is also worth mentioning that the study tool was distributed to teachers and students through its electronic design.

\section{Building and Implementing the Study Tool}

In order to achieve the aims and objectives of the study, two questionnaires were used as the study tool.

The first questionnaire, which consists of the attitudes of teachers towards Blended learning, was developed by examining many scientific studies that dealt with Blended learning from the teachers' point of view and faculty members 
in universities (Almwazbh \& Zaabi, 2020; Saifuddin, 2019; Al-Saleh, 2018; Eshreteh \& Siaj, 2017; Al said, 2011).

The used questionnaire in this study consisted of two dimensions:

The first dimension contained demographic data such as gender. On the other hand, the second dimension included one major variable: the attitudes of teachers towards Blended learning. This dimension consists of twenty-seven statement. The following is a sample of them:

- I see the necessity of using Blended learning in schools.

- Blended learning raises students' motivation to learn.

- Presenting information in a Blended learning method is more interesting to students than the traditional presentation.

- Blended learning neglects many elements of the educational process.

- Blended learning develops students' thinking skills.

- Blended learning increases adherence to a healthy protocol.

- Blended learning encourages the use of electronic technologies.

The Likert scale was used to measure the total score of these statements according to each dimension. This is a fivefold scale, namely: never, rarely, sometimes, often, and always. The weighted arithmetic mean of the scale was determined and presented in Table 1. In order to judge the weighted arithmetic means of questionnaire statements, the scale was divided based on:

$$
\text { Interval length }=\frac{\text { number of intervals }}{\text { number of points }=4 / 5=0.8}
$$

\section{Reliability and Stability of Scale Used}

This refers to the judgment on the virtual scale according to the clarity and meaning of its words, which is based on the second dimension of the study tool. This was carried out by some specialists in e-learning, measurement and evaluation, teaching technologies, curricula, and teaching methods. They also indicated the appropriateness of the proposed data for the test by revising some statements. Moreover, the test-retest method was carried out where a sample was taken from the study population and subjected to the scale two times with four weeks period. The value of the correlation coefficient was found to be 0.91 , which is acceptable for the purpose of the study.

Table 1: Weighted average of Likert scale used to determine the attitudes of teachers toward Blended learning.

\begin{tabular}{lll}
\hline Scale & From & To \\
\hline Never & 1 & 1.79 \\
Rarely & 1.80 & 2.59 \\
Sometimes & 2.60 & 3.39 \\
Often & 3.40 & 4.19 \\
\hline Always & 4.20 & 5
\end{tabular}

The stability of the test was obtained by extracting the stability parameters of the scale used in the internal consistency method by calculating the stability coefficient using the Cronbach-Alpha equation. The total value of stability coefficients for all paragraphs reached 0.834 , which is acceptable and indicates the stability of the study. This is supported by Baumgartner et al. (2002), who stated that if the Cronbach alpha exceeds $60 \%$, the test achieves the stability requirements and the scale is valid. Thus, the data is seen as reliable.

The second questionnaire, which consists of the attitudes of outstanding students towards Blended learning, was developed by examining many scientific studies that dealt with Blended learning from the students' point of view in the different stages of education (school and university education) (Alsalhi et al., 2019; Birbal et al., 2018; Emelyanova \& Voronina, 2017; Ja'ashan, 2015; Al-Sawalha et al., 2013).

The second dimension contained demographic data such as gender educational level. On the other hand, the second dimension included one major variable: the attitudes of students towards Blended learning. This dimension consists of fifteen statement. The following is a sample of them:

- Blended learning helps me use more than one sense in the learning process.

- I feel comfortable and reassured in Blended learning.

- Blended learning increases my motivation to learn.

- Blended learning encourages me to remember and memorize the subject matter.

- Blended learning increases my study follow-up, as it enables me to repeat it anytime and anywhere.

- Blended learning brings about greater commitment to health protocol and public health standards.

- Blended learning simplifies study topics, which helps to understand them better.

The Likert scale was used to measure the total score of these statements according to each dimension. This is a fivefold scale, namely: never, rarely, sometimes, often, and always. The weighted arithmetic mean of the scale was determined and presented in Table 2. In order to judge the weighted arithmetic means of questionnaire statements, the scale was divided based on:

$$
\text { Interval length }=\frac{\text { number of intervals }}{\text { number of points }=4 / 5=0.8}
$$

Table 2: Weighted average of Likert scale used to determine the attitudes of outstanding students toward Blended learning

\begin{tabular}{lll}
\hline Scale & from & To \\
\hline Never & 1 & 1.79 \\
Rarely & 1.80 & 2.59 \\
Sometimes & 2.60 & 3.39 \\
Often & 3.40 & 4.19 \\
Always & 4.20 & 5 \\
\hline
\end{tabular}




\section{Reliability and Stability of Scale Used}

This refers to the judgment on the virtual scale according to the clarity and meaning of its words, based on the second dimension of the study tool. This was carried out by some specialists in e-learning, measurement and evaluation, teaching technologies, curricula, and teaching methods. They also indicated the appropriateness of the proposed data for the test by revising some statements. Moreover, the test-retest method was carried out where a sample was taken from the study population and subjected to the scale two times with four weeks period. The value of the correlation coefficient was found to be 0.90 , which is acceptable for the purpose of the study.

The stability of the test was obtained by extracting the stability parameters of the scale used in the internal consistency method by calculating the stability coefficient using the Cronbach-Alpha equation. The total value of stability coefficients for all paragraphs reached 0.95 , which is acceptable and indicates the stability of the study. This is supported by Baumgartner et al. (2002), who stated that if the Cronbach alpha exceeds $60 \%$, the test achieves the stability requirements and the scale is valid. Thus, the data is seen as reliable.

\section{Statistical Tests}

To answer the main study questions and to prove the hypotheses, statistical analysis and tests such as arithmetic means, standard deviation, independent samples test, Correlations, Levene's Test, and one-way ANOVA test were performed on the collected data using the statistical analysis program (SPSS).

\section{Results and Discussion}

In the following paragraphs, the results of the study will be presented and discussed.

Firstly, it is important to answer the first question raised by the study:

What are the teachers' attitudes towards Blended learning in light of the spread of the Covid-19 pandemic?

The means and standard deviation of the teachers' responses to the components of the questionnaire, which consisted of 27 statements, were calculated. This is shown in Table 3.

To determine the extent of teachers' attitudes towards Blended learning in light of the spread of the Covid-19 pandemic, the arithmetic means and standard deviation of teachers' responses to all paragraphs of the questionnaire were calculated, which is seen in Table 3 above. The analysis showed that the average of all paragraphs was 3.16. This means that the average teachers' answers to the paragraphs were at a moderate degree. The value of the standard deviation from the arithmetic mean was 0.51 , which is less than one. This means that the data values do not disperse much from their arithmetic mean. This can be attributed to the belief and conviction of teachers
Table 3: The means and standard deviation of teachers' answers to the questionnaire statements.

\begin{tabular}{|c|c|c|c|}
\hline & $N$ & Mean & Std. Deviation \\
\hline q1 & 200 & 3.45 & .996 \\
\hline q2 & 200 & 3.48 & 1.012 \\
\hline q3 & 198 & 3.37 & .918 \\
\hline $\mathrm{q} 4$ & 199 & 2.94 & .836 \\
\hline q5 & 196 & 2.95 & .827 \\
\hline q6 & 195 & 2.85 & .823 \\
\hline q7 & 196 & 3.33 & .851 \\
\hline q8 & 196 & 3.40 & .868 \\
\hline q9 & 196 & 3.40 & .974 \\
\hline q10 & 194 & 3.37 & .984 \\
\hline $\mathrm{q} 11$ & 190 & 3.42 & .897 \\
\hline $\mathrm{q} 12$ & 195 & 3.39 & .959 \\
\hline q13 & 200 & 3.23 & .856 \\
\hline $\mathrm{q} 14$ & 200 & 2.88 & .720 \\
\hline q15 & 200 & 2.83 & .809 \\
\hline $\mathrm{q} 17$ & 68 & 3.90 & .736 \\
\hline q18 & 69 & 4.07 & .929 \\
\hline q19 & 69 & 4.13 & .821 \\
\hline q20 & 69 & 2.78 & .704 \\
\hline q21 & 68 & 3.96 & .836 \\
\hline q22 & 69 & 2.70 & .828 \\
\hline q23 & 69 & 2.80 & .677 \\
\hline q24 & 69 & 2.62 & .788 \\
\hline q25 & 69 & 2.55 & .850 \\
\hline q26 & 69 & 2.65 & .638 \\
\hline q27 & 69 & 4.03 & .804 \\
\hline Average general & 200 & 3.1682 & .51870 \\
\hline Valid N (listwise) & 64 & & \\
\hline
\end{tabular}

in the importance of Blended learning, especially in light of the various impacts that the Covid-19 pandemic has created on the education system in Jordan. The Ministry of Education was also interested in qualifying teachers by holding many training courses, introducing educational qualification programs, and encouraging teachers to participate in such programs. The purpose of this is to raise the teacher's competence and facilitate dealing with modern technological technologies, which the Ministry seeks to provide in schools. More so, universities also seek to bring out a conscious generation armed with knowledge and science. This can be achieved by focusing on developing their capabilities and skills, especially in modern technology, and linking them in the education system (Almwazbh \& Zaabi, 2020; Saifuddin, 2019; Birbal et al., 2018; Al-Saleh, 2018; Alsid, 2011). 
Secondly, are there statistically significant differences $(\alpha=0.05)$ between teachers' attitudes towards Blended learning in light of the Covid-19 pandemic according to the gender variable and teaching experience?

In order to answer this question, the t-test was used for two independent samples to examine differences according to the gender. This is shown in Table 4 .

As shown in Table 4, the results of the Independent Samples T-Test revealed that the variance is equal between females and males. This is evidenced by Levene's Test for equal variance, where the value of the level of statistical significance reached 0.06 , which is greater than 0.05 . Also, the results of the t-test when assuming Equal variances showed no statistically significant differences between teachers' attitudes towards Blended learning in light of the Covid-19 pandemic according to the gender variable. This is because the level of statistical significance reached 0.665 , which is greater than 0.05 . Therefore, the null hypothesis is accepted, which states that there are no statistically significant differences between teachers' attitudes towards Blended learning in light of the Covid-19 pandemic due to the gender variable.

Thirdly, are there statistically significant difference between teachers' attitudes towards Blended learning in light of the Covid-19 pandemic due to teaching experience. To demonstrate the result of this hypothesis, an analysis of Pearson Correlation was used as shown in Table 5.

The results of the Pearson Correlation Coefficient analysis (Table 5) showed a statistically inverse relationship at a significance level of $1 \%$. This is seen between teachers' attitudes towards Blended learning in light of the Covid-19 pandemic and teaching experience. Therefore, this indicated a weak degree. This means that the more years of teaching experience, the less teachers are directed towards Blended learning in light of the Covid-19 pandemic. Subsequently, the alternative hypothesis is accepted, which states that there are statistically significant differences between teachers' attitudes towards Blended learning in light of the Covid-19 pandemic due to the teaching experience variable. It is possible to attribute this to the fact that teachers with long teaching experience focus more on traditional education. This makes them often have poor use of technology and its applications. In addition, the stages of learning and qualification in universities and during the service were generally absent from technology and modern learning methods. Although majority of them underwent in-service training and development on modern learning programs and methods. However, the training and development process did not achieve the desired benefits in general. This resulted to the reflection on their views on Blended learning in the Covid-19 pandemic.

Fourthly, what are the outstanding students' attitudes towards Blended learning in light of the spread of the Covid-19 pandemic?

The means and standard deviation of the outstanding students' responses to the components of the questionnaire, which consisted of 15 statements, were calculated. This is shown in Table 6.

To determine the extent of the outstanding students' attitudes towards Blended learning in light of the spread of the Covid-19 pandemic, the arithmetic means and standard deviation of the outstanding students' responses to all paragraphs of the questionnaire were calculated as shown in Table 6 above. The analysis showed that the average of all paragraphs was 3.23. This means that the average of the outstanding students' answers to the paragraphs were at a moderate degree. The value of the outstanding standard deviation from the arithmetic mean was 0.60 , which is less than one. This indicates that the data values do not disperse much from their arithmetic mean. This result is also attributed to the fun achieved through Blended learning and the enrichment in the learning process. Here, the focus is on attracting the outstanding students' attention through technology, excitement, suspense, and modernity. It is also considered a suitable option for most students because of their departure from the ordinary and what is traditional in the educational process. The Covid-19 pandemic has also had a clear impact on students in their tendency to adopt distance learning methods and strategies due to the closures imposed by the pandemic on the education sector. Among the challenges that affect students in effectively adopting mixed learning is the inability to provide technological devices, and the teaching curricula do not effectively serve the Blended learning process (Alsalhi et al., 2019; Eshreteh \& Siaj, 2017; Fakhir, 2015; Akkoyunlu \& Soylu, 2006).

Table 4: T-test for independent samples between teachers 'attitudes towards Blended learning due to gender

\begin{tabular}{|c|c|c|c|c|c|c|c|c|c|c|}
\hline & & \multicolumn{3}{|c|}{$\begin{array}{c}\text { Levene's Test } \\
\text { for Equality of } \\
\text { Variances }\end{array}$} & \multicolumn{6}{|c|}{ t-test for Equality of Means } \\
\hline & & \multirow[b]{2}{*}{$F$} & \multirow[b]{2}{*}{ Sig. } & \multirow[b]{2}{*}{$t$} & \multirow[b]{2}{*}{$D f$} & \multirow{2}{*}{$\begin{array}{l}\text { Sig. } \\
\text { (2-tailed) }\end{array}$} & \multirow{2}{*}{$\begin{array}{l}\text { Mean } \\
\text { Difference }\end{array}$} & \multirow{2}{*}{$\begin{array}{l}\text { Std. Error } \\
\text { Difference }\end{array}$} & \multicolumn{2}{|c|}{$\begin{array}{l}\text { 95\% Confidence } \\
\text { Interval of the } \\
\text { Difference }\end{array}$} \\
\hline & & & & & & & & & Lower & Upper \\
\hline \multirow[t]{2}{*}{ Average general } & Equal variances assumed & 3.590 & .060 & $-.433-$ & 198 & .665 & $-.03185-$ & .07351 & $-.17681-$ & .11312 \\
\hline & Equal variances not assumed & & & $-.434-$ & 184.262 & .664 & $-.03185-$ & .07329 & $-.17645-$ & .11276 \\
\hline
\end{tabular}


Fifthly, are there statistically significant differences between the outstanding students' attitudes towards Blended learning in light of the Covid-19 pandemic due to gender.

This question was answered with the t-test, which was used for two independent samples to examine the differences according to the gender as shown in Table 7.

As shown in Table 7, the results of the Independent Samples T-Test revealed that the variance is equal between females and males. This is evidenced by Levene's Test for equal variance, where the value of the level of statistical significance reached 0.61 , which is greater than 0.05 . In addition, the results of the t-test when assuming Equal variances showed no statistically significant differences between the outstanding students' attitudes towards Blended learning in light of the Covid-19 pandemic according to the gender variable. This is because the level of statistical significance reached 0.68 , which is greater than 0.05. Therefore, the null hypothesis is accepted, which states that there are no statistically significant differences between the outstanding students' attitudes towards Blended learning in light of the Covid-19 pandemic due to the gender variable.

Sixthly, are there statistically significant differences between the outstanding students' attitudes towards Blended

Table 5: Correlation between teachers' attitudes towards Blended learning due to teaching experience

\begin{tabular}{llll} 
& \multicolumn{3}{l}{ learning due to teaching experience } \\
\hline Teaching & $\begin{array}{l}\text { Teaching } \\
\text { experience }\end{array}$ & $\begin{array}{l}\text { Average } \\
\text { general }\end{array}$ \\
\hline experience & Pearson Correlation & 1 & $.295^{* *}$ \\
& Sig. (2-tailed) & & .000 \\
Average & $\mathrm{N}$ & 200 & 200 \\
general & Pearson Correlation & $.295^{* *}$ & 1 \\
& Sig. (2-tailed) & .000 & \\
& $\mathrm{~N}$ & 200 & 200 \\
\hline
\end{tabular}

**. Correlation is significant at the 0.01 level (2-tailed).

learning in light of the Covid-19 pandemic due to grade level? To demonstrate this, One Way ANOVA was used as shown in Table 8.

As shown in Table 8, the results of the One-Way ANOVA revealed no statistically significant differences between the outstanding students' attitudes towards Blended learning in light of the Covid-19 pandemic due to the grade level. This is because the level of statistical significance reached 0.516 , which is greater than 0.05 . Therefore, the null hypothesis is accepted, which states that there are no statistically significant differences between the outstanding students' attitudes towards Blended learning in light of the Covid-19 pandemic due to the grade level.

Table 6: The means and standard deviation of the outstanding students' answers to the questionnaire statements.

\begin{tabular}{llll}
\hline & $N$ & Mean & Std. Deviation \\
\hline q1 & 200 & 3.37 & .942 \\
q2 & 200 & 3.34 & .889 \\
q3 & 198 & 3.26 & .832 \\
q4 & 199 & 3.33 & .817 \\
q5 & 192 & 3.29 & .714 \\
q6 & 193 & 3.28 & .814 \\
q7 & 197 & 3.19 & .717 \\
q8 & 195 & 3.28 & .770 \\
q9 & 196 & 3.21 & .826 \\
q10 & 194 & 3.15 & .825 \\
q11 & 189 & 3.22 & .700 \\
q12 & 195 & 3.13 & .713 \\
q13 & 200 & 3.11 & .745 \\
q14 & 200 & 3.23 & .763 \\
q15 & 200 & 3.20 & .837 \\
Average general & 200 & 3.2379 & .60544 \\
Valid N (listwise) & 166 & & \\
\hline
\end{tabular}

Table 7: T-test for independent samples between the outstanding students' attitudes towards Blended learning due to gender.

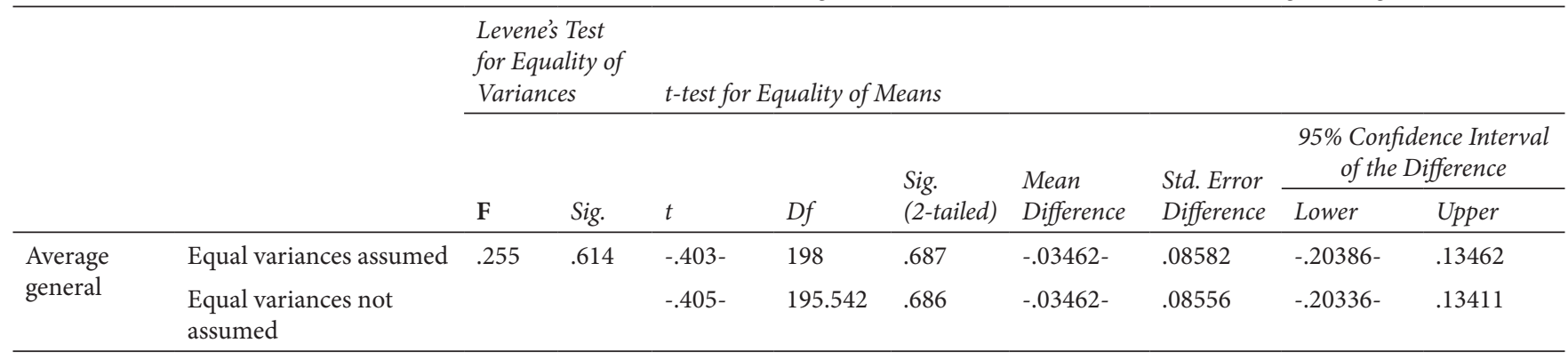

Table 8: One Way ANOVA used to determine the outstanding students' attitudes towards Blended learning due to grade level.

\begin{tabular}{llllll}
\hline Overall average & Sum of Squares & Df & Mean Square & $F$ & Sig. \\
\hline Between Groups & .489 & 2 & .244 & .664 & .516 \\
Within Groups & 72.456 & 197 & .368 & & \\
Total & 72.944 & 199 & & & \\
\hline
\end{tabular}




\section{Conclusions and Recommendations}

This era has become branded with technology. This is because technology has contributed to the creation, acceleration, and development of different walks of life. It has also taken the lead in the processes of development and prosperity. Consequently, it has further played a great role in the education sector and in all its different stages. The Covid-19 pandemic has created many problems in the learning and education system at the international and local levels, especially when schools and universities were closed and switched to distance learning. Therefore, technology and education based on the use of technology effectively contributed to reducing these problems. Blended learning was one of the most important forms and methods of education based on the integration of e-learning and traditional education within the classroom and the combination of both. The results of the study revealed that the attitudes of teachers and outstanding students towards Blended learning in light of the spread of the Corona virus was at an average level. This is considered acceptable to some extent, especially since the education system in Jordan focuses a lot on traditional education. As a result, the infrastructure suffers from a clear weakness in providing technology such as the Internet, computers, electronic curricula, and others. Generally, this is seen in the public and private education sector and among the families of students. In addition, this left negative repercussions on the methods and models of e-learning in Jordan. The study results also revealed that there are no statistically significant differences between teachers' and outstanding students' attitudes towards Blended learning in light of the spread of the Covid-19 pandemic according to gender and according to the grade level from the outstanding students' point of view. Therefore, it is believed that teachers' and outstanding students attitudes towards e-learning in general and Blended learning in particular should be strengthened by providing rewards, incentives, and the necessary equipment and technologies needed for Blended learning. In addition, the use of modern technologies should be encouraged. Emerging technological software should be dealt with by holding training courses and workshops. Finally, the infrastructure for the e-learning system should be developed at the national level.

\section{References}

Abdul Hameed Shoman Cultural Forum (2019). https://www. shoman.org/uploads/2019

Affouneh, S., Salha, S., \& Khlaif, ZN. (2020). Designing Quality E-Learning Environments for Emergency Remote Teaching in Coronavirus Crisis. Interdiscip J Virtual Learn Med Sci.11(2):1-3.

Akkoyunlu, B. \& Soylu, M. Y. (2006). A Study on Students' Views on Blended Learning Environment. Faculty of Education Department of Computer Education and Instructional Technology. Turkish Online Journal of Distance Education,7,43-56.
Al, S. \& Yousry, M. (2011). Attitudes of Gulf University faculty members towards blended learning. Gulf University Journal, 75 (162), 1-71.

Al-Husban, N. \& Shorman, S. (2020). Perceptions of syrian student refugees towards blended learning: Implications for higher education institutions. International Journal of Emerging Technologies in Learning (ijet), 15(1), 45-60.

Al-mwazbh Reda Salama \& Al-Zaabi Talal Abdullah (2020). Attitudes of faculty members in Jordanian universities towards blended education and the difficulties they face in implementing it, Zarqa Journal for Research and Humanitarian Studies, 20 (2), 39-48.

Al-Saleh, R. S. S. (2018). EFL teacher's attitudes towards blended learning in Tabuk, Saudi Arabia. International Journal of Information Research and Review, 5(1), 5065-5071.

Alsalhi, N. R., Eltahir, M. E., \& Al-Qatawneh, S. S. (2019). The effect of blended learning on the achievement of ninth grade students in science and their attitudes towards its use. Heliyon, 5(9), e02424.

Al-Sawalha Ali Suleiman, Mahasna Omar Musa, Al-Momani Mufdi Muhammad, \& Al-Oweimer Yusra Rashid (2013). Attitudes of Al-Balqa Applied University students towards the use of blended education by faculty members in teaching university courses. Journal of Specific Education Research, 28, 223-243.

Baumgartner, T., Strong, C., \& Hensley, L. (2002). Conducting and Reading Research in Health and Human Performance. McGraw-Hill.

Birbal, R., Ramdass, M., \& Harripaul, M. C. (2018). Student teachers' attitudes towards blended learning. J. Educ. Hum. Dev, 7(2), 9-26.

Emelyanova, N. \& Voronina, E. (2017). Introducing blended learning in the English language classroom: Students' attitudes and perceptions before and after the course. Knowledge Management \& E-Learning: An International Journal, 9(1), 33-49.

Fakhir, Z. (2015). The impact of blended learning on the achievement of the English language students and their attitudes towards it. Unpublished master's thesis. Middle East University, Amman.

Ja'ashan, M. M. N. H. (2015). Perceptions and Attitudes Towards Blended Learning for English Courses: A Case Study of Students at University of Bisha. English Language Teaching, 8(9), 40-50.

Khan, M. S. \& Abdou, B. (2020). Flipped Classroom: How Institutions of Higher Education (HEIs) of Bangladesh Could Move Forward During Covid-19 Pandemic. Available at SSRN: https:// ssrn.com/abstract $=3615400$.

KM Eshreteh, M. \& Hisham Siaj, A. (2017). Attitudes of English-major students and teachers towards using blended learning in the English department at Hebron University. International Journal of Research in English Education, 2(4), 51-65.

Saifuddin, S. R. (2019). An Investigation of Academics' and Administrators' Perceptions of Blended Pedagogies at Saudi Universities. https://www.dora.dmu.ac.uk/handle/2086/18299

Taylor, J. C. (1995). Distance education technologies: The fourth generation. Australasian Journal of Educational Technology, $11(2), 1-7$

UNESCO (2020). Covid-19 Impact on Education Data, COVID-19 Education Disruption and Responsekl, the United Nations Educational, Scientific and Cultural Organization, ParisFrance. https://en.unesco.org/news/covid-19-webinar-newworldteachers-educations-frontline-workers 